Egyptian Poultry Science Journal

http://www.epsaegypt.com

ISSN: 1110-5623 (Print) - 2090-0570 (On line)

\title{
SEROPREVALENCE OF SALMONELLA GALLINARUM INFECTION IN FREE-RANGE CHICKENS REAREDIN NASARAWA STATE, NIGERIA.
}

\author{
A. E.Salihu, ${ }^{1}$, Onwuliri, F C ${ }^{\mathbf{2}}$, Mawak, J. D ${ }^{\mathbf{3}}$, Kalshingi, H. A ${ }^{\mathbf{4}}$ and Hassan, D. I ${ }^{\mathbf{5}}$ \\ ${ }^{1}$ Virology Dep., Federal Coll. of Vete. and Med. Lab. Tech. Vom, P.M.B 02 Vom, Plateau \\ State, Nigeria. ${ }^{2}$ Dep. of Plant Sci. and Tech., Fac. of Nat. Sci., Univ. of Jos. P.M.B 2084, Jos \\ Plateau State, Nigeria. ${ }^{3}$ Dep. of Mic., Fac. of Nat. Sci., Univ. of Jos. P.M.B 2084, Jos, \\ Plateau State, Nigeria. ${ }^{4}$ Dep. of viral Vaccine Prod., Nat. Vete. Rese. Insti. Vom, P.M.B 01, \\ Vom, Plateau State, Nigeria. \\ ${ }^{5}$ Anim.Science Dep., Coll. of Agric. Lafia, Nasarawa State, Nigeria.
}

\begin{abstract}
The study determined the seroprevalence of S. gallinarum infection in freerange chickens in Nasarawa State, Nigeria. A total of 2772 serum samples collected from free-range chickens in 12 selected villages/towns in Nasarawa State were screened for specific antibodies against $\mathrm{S}$. gallinarum by the rapid serum agglutination method. Overall, $236(8.5 \%)$ of the chickens had detectable antibodies against S. gallinarum. Nasarawa South Senatorial Zone had a significantly higher $(\mathrm{p}<0.05)$ antibody prevalence of 109 (9.5\%) when compared with Nasarawa North, 59 (8.5\%) and Nasarawa West, 68 (7.2\%). There was significant difference $(\mathrm{p}<0.05)$ in $\mathrm{S}$. gallinarum antibody prevalence in chickens sampled from individual villages/towns, with Assakio, Keana and Wamba having significantly higher antibody prevalence rates of 17 (21.3\%), $21(21.0 \%)$ and $16(20.0 \%)$, respectively. A significant difference $(p<0.05)$ was observed in the prevalence of $S$. gallinarum antibody in the sampled chickens in relation to age, and prevalence was found to be higher $(\mathrm{p}<0.05)$ in the older.birds Thus chickens of age greater than 34 weeks and 28-34 weeks had antibody prevalence of $47(13.4 \%)$ and $57(10.0 \%)$, respectively. S. gallinarum antibody prevalence was significantly higher $(\mathrm{p}<0.05)$ in the rainy season (June to October) $126(10.5 \%)$ with the highest infection peak in September, when compared with the dry season (December to May), 110 (7.0\%). The layer chickens had a significantly higher $(\mathrm{p}<0.05)$ antibody prevalence of $138(19.1 \%)$ compared with cockerel, $60(5.3 \%)$ and pullets, $38(4.1 \%)$. The detection of S. gallinarum antibody in theseunvaccinated apparently healthy chickenssconfirms the presence of fowl typhoid. Since these birdss are
\end{abstract}

Key Words: Seroprevalence, S. gallinarum, Infection, Free-range chickens, Nigeria.

Corresponding author: ${ }^{1}$ saluela@yahoo.com 
usually managed under the extensive system, they could contribute to further spread of the infection in the environments. This could threaten the development of poultry industry in Nasarawa State, Nigeria.

\section{INTRODUCTION}

Salmonella gallinarum

(S. gallinarum) is an avian adapted bacterial pathogen and the causative agent of fowl typhoid (Abdul, 2007; OIE Manual, 2008); a severe systemic disease which affects primarily chickens and turkeys (Lee et al., 2005)with geographical distribution in Mexico,Central and South America, Africa, and Asia and the Indian subcontinent (OIE, 2005).

Fowl typhoid is principally associated with an acute septicaemic illness of high morbidity and mortality in birds during the later growing period and in adult (AHVLA, 2012), but it may occur in young chickens where it is indistinguishable clinically from pullorum disease (OIE Manual, 2000).

In Nigeria, the incidence of $\mathrm{S}$. gallinarum was first reported in in 1930. Since then it has been reported in different parts of the country (Data on livestock disease diagnosis, National Veterinary Research Institute (NVRI), Vom). The disease has affected both government and private farms and has also been found in birds in the chicken markets (Nwobu et al., 1990). According to the Annual Animal Health Report on the Notification of the Absence or Presence of All Diseases in Nigeria (FLDPCS, 2010) and data onthe diagnosis of animal diseases obtained from the Central Diagnostic Division of National Veterinary Research Institute, Vom, Nigeria, fowl typhoid ranks higher among the bacterial diseases of poultry, causing huge economic losses to commercial poultry farmers.

The demand for poultry products in Nigeria has increased in recent past, especially as more people have realized the nutritional and economic values of chickenand their products. Consequently, many poultry farms have sprung up particularly in and around the urban centres. This is now a commercial enterprise involving thousandsof chickens estimated at 203.4 million. Of this population, Nasarawa State has an estimated poultry population of $863,647.7$, comprising 777,282.9 local breeds and 86,364.8 exotic breeds (FLPCS, 2011). This has become a diverse industry with variety of business interests such as egg production, meat production, hatchery and poultry equipment marketing

The free range poultry otherwise known as rural poultry in Nigeria is made up mostly of chickens, ducks, and guinea fowls, which are domesticated for the purpose of egg and meat production. These are managed under the extensive systems (Emikpe et al, 2005), and are usually not vaccinated (Adu et al, 1986). It is widely believed that they act as reservoirs of most important poultry diseases, including fowl typhoid. (Bouzoubaa et al, 1992) Chickens (Gallus gallus domesticus) are the most important of the free range poultry species in terms of number and development (Oluyemi and Roberts, 1979). They are kept by over $90 \%$ of rural households, especially women, as assets (Ajala et al., 2007), providing an important source of high quality protein as well as a source of income for the families (Abubakar et al, 2008).

In Nigeria, the local chickens form the bed-rock of the poultry industry, contributing over $80 \%$ of poultry products (NAERLS, 2000). They represent a significant part of the rural economy in particular and of the national economy as a whole (Ajala et al., 2007). For example, in 1988 the rural poultry constituted $43 \%$ and $89 \%$ of the national egg and meat 
production respectively, with an annual output of 67,000 metric tons of meat and 82,000 metric tons of eggs (Adegeye et al, 1988). This category of birds is however faced with all kinds of hardships, such as poor management, lack of external input for production, and disease. Of these constraints, disease remains a major limiting factor in their production. The diseases that cause significant morbidity and mortality in poultry include bacterial, viral and parasitic diseaseas. Among the bacterial diseases affecting chickens, fowl typhoid is significant because its causal agent is transmitted vertically from parent to offspring (Akter et al., 2007).

Prevention of Salmonella infection is important for the profitable expansion of poultry industry in Nigeria. This isnecessitated by the fact that, with the continuous expansion of poultry farming in Nigeria, avian salmonellosis caused by $\mathrm{S}$. gallinarum has also gained ground as a major disease of poultry (Agbaje et al, 2010), resulting into heavy economic loss through mortality and reduced egg production. Effective prevention and control measures of the disease cannot be undertaken unless its status and epidemiology are well elucidated.

A definite diagnosis of fowl typhoid requires the isolation and identification of S. gallinarum. However, a tentative diagnosis can be made based on the flock history, clinical signs, mortality and lesions. Positive serological findings are of great value in detecting infection (Barrow et al, 1992).

The aim of this study was to determine the seroprevalence of $\mathrm{S}$. gallinaruminfection in free range chickens in Nasarawa State, Nigeria.

\section{MATERIALS AND METHODS}

\section{Study Area:}

Nasarawa State is located in the North Central Nigeria otherwise known asthe Middle-Belt region, with Lafia as its capital. The state is divided into 13 Local Government Areas (LGA) for administrative purposes, which are further grouped into three senatorial zones. Nasarawa State is bounded in the north by Kaduna State, in the west by the Federal Capital Territory, in the south by Kogi and Benue States and in the east by Taraba and Plateau States.The state has agriculture as the mainstay of its economy and is located between latitude $85^{\circ} \mathrm{N}$ and longitude $8^{\prime} 32^{\circ} \mathrm{E}$, with mean temperature of $32^{\circ} \mathrm{C}$ (Hassan et al, 2013). Nasarawa State has a total area of $27,117 \mathrm{Km}^{2}$ and population of 2, 040, 097 with density of $75 / \mathrm{km}^{2}$ (190/sq mi), according to 2005 Nigerian National Cencus.

\section{Identification and selection of study areas:}

A preliminary field investigation was carried out in Nasarawa stateto identify the study sites. Three villages and a local government headquarter were randomly selected from each senatorial zone of the state.A total of 12 villages/towns were selected, which included Lafia, Keana, Agbashi and Asakkio from Nasarawa South Senatorial Zone; Akwanga, Andaha, Nasarawa Eggon and Wamba from Nasarawa North Senatorial Zone, and Keffi, Garaku, Gadabuke and Gunduma from Nasarawa West Senatorial Zone. They selected villages/towns are located in 10 (76.9\%) out of the 13 LGAs of the State.

\section{Sampling procedure:}

A stratified random sampling technique was employed in selecting the flocks. A total of 83 households were randomly selected from the selected villages and, all chickens in a selected household were considered as one flock (Mdegela et al, 2000). The number of flocks selected per area ranged from eight to ten and, from each of these households $10 \%$ of the total flock population was sampled (Mdegela et al, 2000; Peter et al, 2006). In the local government 
headquarters, samples were collected from chicken markets, and one chicken market was selected from each local government to represent the senatorial zone.

\section{Sample collection and processing:}

Blood samples

were collectedbetween January andDecember 2006 from unvaccinated apparently healthy free range chickensof various types (pullets, cockerels and layers) and ages through the wing vein using sterile $5 \mathrm{ml}$ syringe and $21 \mathrm{G}$ needles.Three mililitres of blood was collected from each bird. Blood was kept in a standing position in syringe until clot formation and serum was harvested by decanting (Mozaffor et al, 2010). The harvested sera were transferred to $1.5 \mathrm{ml}$ micro centrifuge tubes and kept in cold box before shipping to the laboratory.Sera were stored at $-20^{\circ} \mathrm{C}$ until use for the Rapid Serum Agglutination Test (Selvan etal, 2010). A total of 2,772 blood samples comprising 927 from Nasarawa South Senatorial Zone, 907 from Nasarawa North Senatorial Zone and 938 from Nasarawa West Senatorial Zone were collected. From the total number of samples collected, 1,942 were from chicken markets, which comprised 864 from Lafia, 430 from Akwanga and 648 from Keffi markets

\section{Salmonella. gallinarum antigen:}

The method described by Mona et al (2012) was used to prepare the antigen. Samples from visceral organs (spleen and liver) collected at postmortem from chickens experimentally infected with field strain of S. gallinarum obtained from Central Diagnistic Department of N.V.R.I, Vom were cultured for the isolation of $S$. gallinrum. The organism was was identified according to Quinn et al (2002) and subsequently subcultured onto nutrient agar containing $1 / 800$ phenol. This was heated to inactivate $\mathrm{Vi}$ antigen (if present) and to obtain much growth of $S$. gallinarum. The culture was incubated at $37^{\circ} \mathrm{C}$ for 24 hours, and bacterial growth on agar surface was harvested into $10 \mathrm{ml}$ nutrient broth by scraping using sterile wire loop. The pure culture of S. gallinarum in nutrient broth was shaken overnight at $37^{\circ} \mathrm{C}$. Thereafter, broth culture was centrifuged at $5000 \mathrm{xg}$ for 60 minutes and the pellets was resuspended and washed three times in $10 \mathrm{ml}$ phosphate buffered saline. The pellets were broken using a sonicator (Fisher Model 300, UK) at power $6 \%$ and centrifuged again at $5000 \mathrm{xg}$ for 60 minutes. The suspension was checked for purity and sterility (test for absence of bacterial and fungal contaminants) using nutrient agar and Sabourad dextrose agar. Pure S. gallinarum culture suspension was stored at $-20^{\circ} \mathrm{C}$ until used for Rapid Serum Agglutination Test (RSAT).

\section{Salmonella gallinarum positive control serum:}

The sera were prepared according to procedure described by Okwori et al (2007). Three adult chickens with no sign of clinical salmonellosis, which were obtained from the poultry department of the National Veterinary Research Institute (NVRI), Vom, were used. Each of the chickens was intramuscularly inoculated with $0.5 \mathrm{ml}$ of inactivated cultures of $\mathrm{S}$. gallinarum containing $10^{6} \mathrm{cfu} / \mathrm{mlobtained}$ from the Bacterial Vaccine Production Department, NVRI, Vom. Chickens were kept for 28 days and observed for immunological response typical of $\mathrm{S}$. gallinarum infection. Sera were thereafter collected at $1^{\text {st }} 2^{\text {nd }} 3^{\text {rd }}$ and $4^{\text {th }}$ weeks post infection and standardized with $\mathrm{S}$. gallinarumreferenceantigen obtained from NVRI, Vom, after each collection. Avid sera werepooled anddispensedin one $\mathrm{ml}$ aliquots as positive control serum. Serum was preserved at $-20^{\circ} \mathrm{C}$ until required.

\section{Salmonella gallinarum negativecontrol serum: \\ Negative control serum wasprepared in the same manner, but}


chickens were injected with sterile distilled water obtained from Bacterial Vaccine Production Department, NVRI, Vom. Sera obtained were standardized with a reference S. gallinarum antigen alsoobtained from the Bacterial Vaccine Production Department, NVRI, Vom. Sera were pooled and stored at $-20^{\circ} \mathrm{C}$ as negative control serum.

\section{Rapid serum agglutination test:}

The test was performed as described in OIE Manual (2008) to detect S. gallinarum antibody in the field serum samples. The locally prepared S.gallinarum antigen was allowed to warm up to room temperature prior to test. With the aid of a sterile disposable plastic Pasteur pipette, a drop $(0.02 \mathrm{ml})$ of the antigen was placed on the centre of each square of ruled clean white ceramic tile. An equal volume of serum was placed next to the antigen, and the reagents were mixed using fine glass rod, which was wiped clean between samples. The mixture was agitated using gentle rocking for up to 2 minutes. A positive reaction was indicated by easily visible clumping of the antigen within 2 minutes, while negative reaction was indicated by absence of clumping of antigen within 2 minutes. The previously prepared positive and negative control sera were included on each testing occasion, treated in the same manner as test samples. On completion of a set of tests, the tile was washed and dried, ready for further use.

\section{Statistical analysis:}

The data generated were statistically analysed byChi-squaremethod usingthe Statistical Package for the Social Sciences (SPSS) software version 17.0.

\section{RESULTS}

The overall seroprevalent rate is shown in table 1. Eight and half percent of the sampledchickens had detectableantibody to $\mathrm{S}$. gallinarum. The proportion of serologically positive chickens in the individual villages/towns ranged from $5.6 \%$ in Nasarawa Eggon in Nasarawa North Senatorial Zone to $21.3 \%$ in Assakio in Nasarawa South Senatorial Zone

(Table 1)

Table (1): Prevalence of S. gallinarum Antibody in Free Range Chickens in Nasarawa State, Nigeria in Relation to StudyLocations

\begin{tabular}{|l|l|l|l|l|}
\hline \multicolumn{1}{|c|}{ Location } & $\begin{array}{c}\text { No. of } \\
\text { Flocks }\end{array}$ & $\begin{array}{c}\text { No. of Sera } \\
\text { Tested }\end{array}$ & No.Positive & \% Positive. \\
\hline Lafia & - & 864 & 60 & 6.9 \\
Keana & 10 & 100 & 21 & 21.0 \\
Agbashi & 10 & 100 & 11 & 11.0 \\
Assakio & 8 & 80 & 17 & 21.3 \\
Akwanga & - & 430 & 29 & 6.7 \\
Andaha & 9 & 90 & 9 & 10.0 \\
Wamba & 8 & 80 & 16 & 20.0 \\
N/Eggon & 9 & 90 & 5 & 5.6 \\
Keffi & - & 648 & 42 & 6.5 \\
Garaku & 10 & 100 & 11 & 11.0 \\
Gadabuke & 10 & 100 & 9 & 9.0 \\
Gunduma & 9 & 90 & 6 & 6.7 \\
Total & 83 & 2772 & 236 & 8.5 \\
\hline Significat $(p<0.05$ & \multicolumn{3}{|l}{} \\
\hline
\end{tabular}

Significant $(\mathrm{p}<0.05$ 
Table 2 presentss the distribution of S. gallinarum antibody in the senatorial zones of the Nasarawa State.It showed that Nasarawa South Senatorial Zone had the highest antibody prevalenceof $9.5 \%$, followed by the Nasarawa North, $8.5 \%$ and Nasarawa West $7.2 \%(\mathrm{p}<0.05)$.

Table (2): Prevalence of S. gallinarum Antibody in Free Range Chickens in Nasarawa State, Nigeria in Relation to Senatorial Zones

\begin{tabular}{|l|l|l|l|}
\hline \multicolumn{1}{|c|}{ Senatorial Zone } & \multicolumn{1}{c|}{$\begin{array}{c}\text { No. of Sera } \\
\text { Tested }\end{array}$} & \multicolumn{1}{c|}{ No. Positive } & \multicolumn{1}{c|}{$\begin{array}{c}\text { Positive } \\
\text { Pasarawa South }\end{array} 1144$} \\
Nasarawa North & 690 & 109 & 9.5 \\
Nasarawa West & 938 & 59 & 8.5 \\
Total & 2772 & 68 & 7.2 \\
\hline
\end{tabular}

Not significant $(\mathrm{p}>0.05)$

The percentage detectable S. 8-12 week-old, 6.9\% for 13-16 week-old, gallinarumantibody in relation to age of $7.7 \%$ for $17-19$ week-old, $8.1 \%$ for $21-27$ chickens as presentedin table 3 shows that antibody prevalence increased with advancement in age. Thus antibody prevalenceincreased in this order: $6.0 \%$ for week-old, $10.0 \%$ for $28-34$ week-old and $13.4 \%$ for chickens greater than 34 week of aget ( $p>0.05)$.

Table (3): Prevalence of S. gallinarum Antibody in Free Range Chickens in Nasarawa State, Nigeria in Different Ages

\begin{tabular}{|l|l|l|l|}
\hline \multicolumn{1}{|c|}{ Ages (Weeks) } & \multicolumn{1}{c|}{$\begin{array}{c}\text { No. of Sera } \\
\text { Tested }\end{array}$} & No.Positive & \% Positive \\
\hline $8-12$ & 544 & 33 & 6.0 \\
$13-16$ & 489 & 34 & 6.9 \\
$17-19$ & 414 & 32 & 7.7 \\
$21-27$ & 405 & 33 & 8.1 \\
$28-34$ & 570 & 57 & 10.0 \\
$>34$ & 350 & 47 & 13.4 \\
Total & 2772 & 236 & 8.5 \\
\hline
\end{tabular}

Significant $(\mathrm{p}<0.05)$ 
Table 4 shows the monthly distribution of S. gallinarum antibody. Antibody prevalence washighest in September (18.5\%) and lowest in February (2.3\%).Two peaks of S. gallinarum infection were observed, one in July and the other in September (Figure 1), which are months of rainy season in the study areas. Thus a significantly high $(\mathrm{p}<0.05)$ seroprevalence of $\mathrm{S}$. gallinarum infection was observed during the rainy season (10.5 $\%)$ when compared with dry season $(7.0 \%)$. (Table 5)

Table (4): Monthly Distribution of S. gallinarum Antibody in Free Range Chickens in Nasarawa State, Nigeria.

\begin{tabular}{|l|l|l|l|}
\hline \multicolumn{1}{|c|}{ Month } & $\begin{array}{c}\text { No. of Sera } \\
\text { Tested }\end{array}$ & No. Positive & \% Positive \\
\hline January & 264 & 15 & 5.7 \\
February & 297 & 8 & 2.3 \\
March & 278 & 7 & 2.5 \\
April & 200 & 11 & 5.5 \\
May & 202 & 13 & 6.4 \\
June & 200 & 19 & 9.5 \\
July & 191 & 23 & 12.0 \\
August & 203 & 23 & 11.3 \\
September & 200 & 37 & 18.5 \\
October & 233 & 24 & 10.3 \\
Noveember & 243 & 26 & 10.7 \\
December & 261 & 30 & 11.5 \\
Total & 2772 & 236 & 8.5 \\
\hline
\end{tabular}

Significant $(\mathrm{p}<0.05)$ 


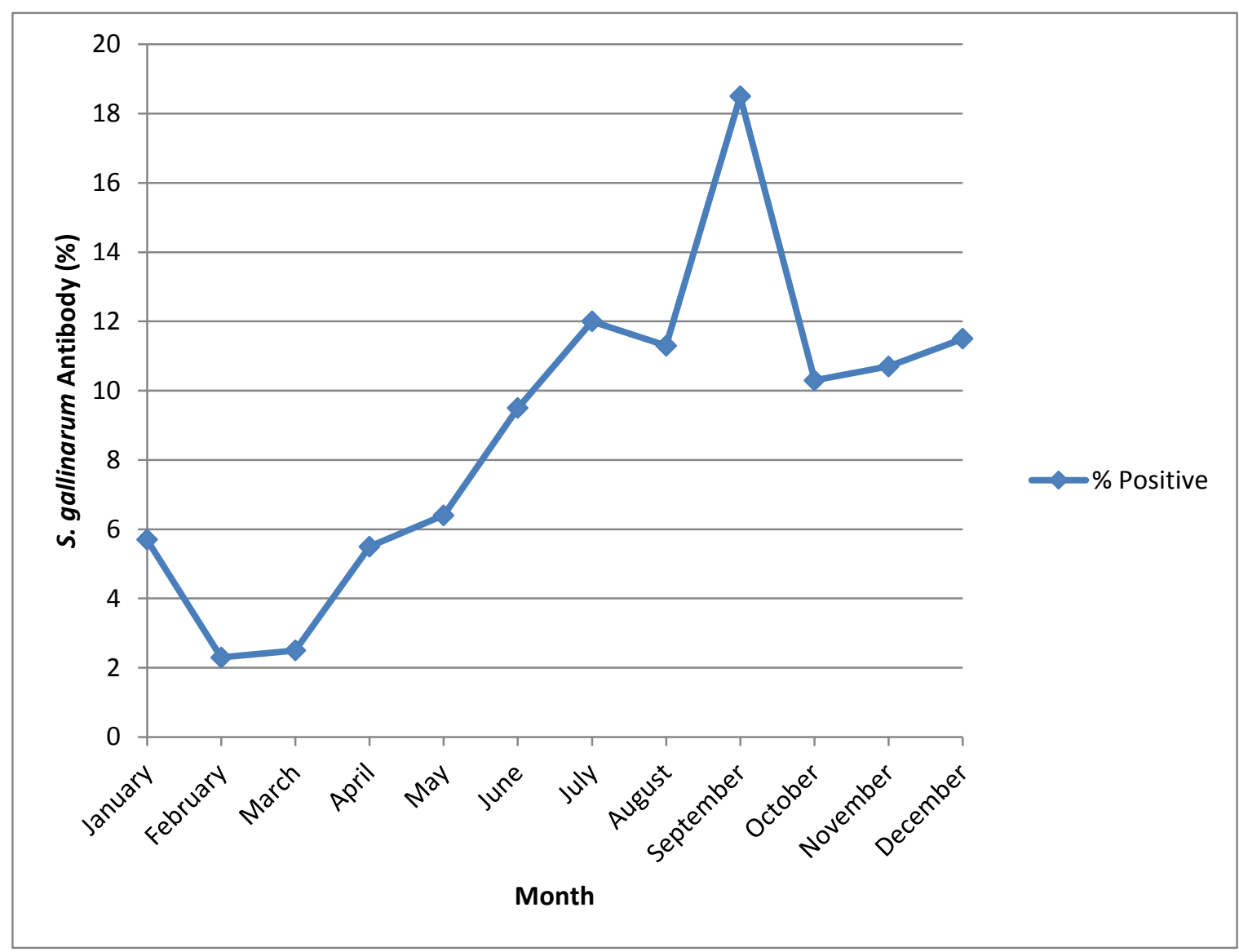

Figure (1): Peak Periods for Seroprevalence of S. gallinarum Infection in Free Range Chickens in Nasarawa State, Nigeria

Table (5): Prevalence of S. gallinarum Antibody in Free RangeChickens in Nasarawa State, Nigeria in Relation to Season

\begin{tabular}{|l|l|l|l|}
\hline \multicolumn{1}{|c|}{ Season } & \multicolumn{1}{c|}{$\begin{array}{c}\text { No. of Sera } \\
\text { Tested }\end{array}$} & \multicolumn{1}{c|}{$\begin{array}{c}\text { No. } \\
\text { Positive }\end{array}$} & \multicolumn{1}{c|}{$\begin{array}{c}\text { \% } \\
\text { Positive }\end{array}$} \\
\hline Dry & 1576 & 110 & 7.0 \\
Rainy & 1196 & 126 & 10.5 \\
Total & 2772 & 236 & 8.5 \\
\hline
\end{tabular}

Significant $(\mathrm{p}<0.05)$

The seroprevalence of S. gallinarum infection for the different types of chickens sampled is shown in table 6. The layer chicken had a seroprevalence of $19.1 \%$, which was significantly higher $(\mathrm{p}<0.05)$ than the $5.3 \%$ and $4.1 \%$ recorded for cockerels and pullets, respectively. 
Table (6): Prevalence of S. gallinarum Antibody in Free Range Chickens inNasarawa State, Nigeria in Relation to Type of Chicken

\begin{tabular}{|l|l|l|l|}
\hline \multicolumn{1}{|c|}{ Type of Chicken } & \multicolumn{1}{c|}{$\begin{array}{c}\text { No. of Sera } \\
\text { Tested }\end{array}$} & \multicolumn{1}{c|}{$\begin{array}{c}\text { No. } \\
\text { Positive }\end{array}$} & \multicolumn{1}{c|}{$\begin{array}{c}\text { Positive } \\
\text { Pollet }\end{array}$} \\
\hline Layer & 723 & 38 & 4.1 \\
Cockerel & 1128 & 138 & 19.1 \\
Total & 2772 & 60 & 5.3 \\
\hline
\end{tabular}

Significant $(\mathrm{p}<0.05)$

\section{DISCUSSION}

In this study, S. gallinarum antibody was detected inunvaccinated apparently healthy free range chickens sampled in Nassarawa State., although, the role of other group D Salmonellae, , which crossreacts with S. gallinarum (Kim et al, 1991), can not be ruled out. However, epidemiological studies show that S.gallinarum infection is endemic in Nigeria (Agbaje et al, 2010; Fasure et al; 2012). The non detection of antibody in the remaining samples may however be due to delayed appearance of agglutinating antibodies in the sampled birds, which takes 3-10 or more days after infection (OIE, 2005).

The presence of antibody in these birds is indicative of bacterial activity, and a serological evidence of fowl typhoid infection in these birds (Mdegela et al, 2000; Peter et al, 2006; Okwori et al, 2007; Ahmed et al, 2008; Mozaffor et al, 2010). This suggests that the birds werepreviouslyinfected by $\mathrm{S}$. gallinarum but have produced antibodies against the organism, hence presumed to be protected.

The free range chickens might have been exposed to the organism probably through contact with infected wild birds, rodents and flies especially mites, which according to valiente et al (2009) may be important mechanical spreaders of $\mathrm{S}$. gallinarum. It is also probable that under poor biosecurity systems in commercial poultry houses, the organism may spread to free-range chickens through commercial poultry workers, most of who also keep these birds and to which they often attend before resuming work at the commercial poultry farms (Ibu, 2008). Further spread of the organism in the study environments probably occurred as a result of inhalation of Salmonella by birds in close contact when pecking at contaminated surface of infected birds (Field Manual of Wildlife Diseases, 2001). Also, infected faeces contribute to contaminating the feeds and drinking water of birds, which could result to further spread of the organism. Once infected, birds remain carrier for very long; over 40 weeks, and shed the organism in faeces (Peter et al, 2006). This could promote the continuous circulation of the organism in the environments and thusexposes the seronegative chickens, and other domestic birds sharing the same environments with the infected chickensat risk of being infected by S. gallinarum.

Theseroprevalence of S.gallinarum infection in free range chickens observed in this investigation is low and similar tothe levelsreported in Nigeria by previous authors (Salami et al, 1989; Ohore et al, 2002; Okwori et al, 2007). A similar level has also been reported from Mauritania (Bell et al, 1990), Morocco (Bouzoubaa et al, 1992), Benin (Chrysostome et al 1995) and Senegal (Arbelot et al, 1997) and Tanzania (Mdegela et al, 2000), and it shows that infection rate in free-range chickensis normallylow. This is probably because, although fowl typhoid is transmitted both horizontally and vertically 
(Peter et al, 2006), in cases where the disease is transmitted horizontally, contaminated feed and drinking water are the main sources of infection and, under the extensive systems of management, as in village poultry production, the chances of chickens eating and drinking contaminated materials is minimal, hence infection rate is usually low in scavenging local chickens when compared with commercial chickens which are reared under intensive management systems, of which the environmental condition favours the survival and multiplication of $\mathrm{S}$. gallinarum,and the chances of chickens eating and drinking contaminated materials is high.

Although there is paucity of published information on the seroprevalance ofS. gallinarum infection in free range chickens in Nasarawa State, seroprevalence of this organism has been reported in the neighbouring states of Plateau(Onunkwo \& Onoviran 1978 and Okwori et al2007) and Kaduna (Salami et al, 1989and Mbuko et al, 2009). These authors documented prevalence of $3.2 \%$ and $9.3 \%$ in Plateau State and $8.4 \%$ and $18.4 \%$ in Kaduna State, respectively. It is important to note that Nasarawa, Plateau and Kaduna States are located in north central Nigeria. It is therefore evident that fowl typhoid isendemicin the region. Also in supportof the present finding are the reports of Adesiyun et al (1984); Falade \& Ehizokhale (1981); Adamu et al (2009) who reported seroprevalence of fowl typhoid in free range poultry in some parts of Nigeria. The present finding is further buttressed by the reports on seroprevalence of this organism in free-range poultry from other developing countries of Asia and Africa such as Bangladesh (Rahman et al, 2011), Tanzania (Mdegela et al, 2000) Uganda (Peter et al, 2006), Morocco (Bauzoubaa et al 1992).Evidence of S. gallinarum infection in scavenging chickens have also been reported by Jha et al.(1995), Arsenault et al (2007), Islam et al. (2006), Jai Sunder et al. (2007)and Habib-ur-Rahman et al. (2003), who documented $18.4 \%, 21.3 \%, 61.68 \%$, and $63.5 \%$, seroprevalence, respectively, which were higher than the rate observed in the present study. The variation in infection rate may be a reflection of difference in geographical distribution of the disease.

In this study, S. gallinaruminfection was detected in chickens sampled from all the study sites. Eventhough statistically significant variation $(\mathrm{p}<0.05)$ was observed in the disease prevalence, with Assakio, Keana and Wamba having significantly higher infection rates compared with the relatively low rates in Nasarawa Eggon, Keffi and Akwanga, it is evident that fowl typhoid is widespread in Nasarawa State. The variation in seroprevalence may however be a reflection of differences in rates of $\mathrm{S}$. gallinarum activity in the infected chicken and their immune status, exposure rate of chickens to the organism, the impact of environment on the survival and multiplication of S. gallinarum and its epidemiology, and geographical distribution of the bacteria.

Seroprevalence was significantly higher $(p<0.05)$ in the southern senatorial zone of Nasarawa State, the zone observed to have the highestpopulation of commercial poultry farms and where the state capital is located. Thisis expected to result to high business activities involving buying and selling of poultry and poultry products. Exchange of egg trays and movement of birds during buying and selling may contribute to spread of the organism in the area. It is also expected thatvaccination activities, which is fundamental in commercial poultry production, will beroutinely carried out. The vaccine strain of $S$. gallinarum could spread to to free-range birds through commercial poultry attendants (Peter et al, 2006), most of who hail from households where scavenging local chickens are kept The 9R vaccine strain of $\mathrm{S}$. gallinarum causes mild systemic salmonellosis in 
chicken with pathology in the liver and spleen, and bacterial persistence for several weeks at these sites (Wingley et al, 2005 and Silva et al, 1981). This may have probablycontributedto the higherseroprevalence of the diseases in Assakio, Keana and Agbashi, which are the closest study villages to the state capital. S gallinarum infection also observed in chickens from other villages might have resulted fromcontact with infecteddomestic birds, wild birds, rodents and flies, which are reservoirs of $\mathrm{S}$. gallinarum. Besides, in these rural commununities poor hygienic conditions were observed. This might have contributed to spread of bacterial diseases in the environments. The application of coordinated policy on hygienic measures has contributedto the eradication of $S$. gallinarum in many developed countries (Barrow, 1993).

The serological evidence of $\mathrm{S}$. gallinarum infection observed in chickens from chicken markets is supported by the report of Nwobu, (1990), who reported fowl typhoid infection rate of $2 \%$ in local chickens at chicken markets in Jos, Nigeria. The chicken markets serve as centre for purchase and slaughter of chickens and other birds. In some of these markets, it was observed that free range chickens, commercial chickens and other domestic birds were kept in close contact in cages for sale, sharing the same feed and drinking water. In such situation, horizontal spread of the organism can not be ruled out. Also, poultry slaughter men who had direct contact with infected birds may serve as vehicle of spread of the bacteria to birds in the markets and in their homes.

In this study, seroprevalence occurred all year round but wasobserved to occur mostly from June to Novemmber, with the highest infection peak in September. This is similar to the finding of Mbuko et al, (2009) who reported high prevalence of fowl typhoid from July to December in Zaria. A similar observation was alsoreported by Roa (2000) in whose report showed that outbreaks of fowl typhoid were mostly seen in summer particularly when the weather is wet and moisture is persistent in the air. The ISO (1993) showed that the disease has three peaks; one continues peak from June to July followed by July to August and another one from October to December. It is important to note that these months fall within the rainy season in most parts of Nigeria, including the study areas. These months are characterized by wet weather and it is the period of high egg production (Calnek, 1995). The consequenceof this is increase in production of infected eggs, which results to increase chick infection.This probably caused the significantly higher $\quad(p<0.05)$ seroprevalence of $\mathrm{S}$. gallinarumin the wet season as observed in the present study.

It was observed in this study that $S$. gallinarum infection rate increased with advancement in age of the chicken. Thus chickens greater than 34 weeks of age had significantly higher $(\mathrm{p}<0.05)$ infection rate of $13.4 \%$, followed by the $28-34$ week-old chickens $10.0 \%$, then the $21-27$ week-old $8.1 \%$ and the least rate of $6.0 \%$ in the $8-12$ week-old chickens, which were the youngest of the chickens sampled.This also shows that chickens of all ages are susceptible to $\mathrm{S}$. gallinarum infection. This corroborates the findings of Jordan and Pattison (1996); Calnek (1995); OIE (2008); Field Manual of Wildlife Diseases (2001), who reported that fowl typhoid generally infects growing and adult birds as well as young birds.

The high infection rate observed among chickens above the age of 21 weeksis expected since at this age, under normal conditions, chickens would commence laying eggs, which continues as the chicken advance in age. The stress of egg production contributes to their inability to resist infection (Saidu et al, 1994). Also, keepinglayers for longer time than other types of flocks expose them to risk of long time exposure to $\mathrm{S}$. gallinarum as a result 
of natural infection (Peter et al, 2006). Once infected, the layer chickens will continue to produce infected eggs to perpetuate the circle of infection (Shiraprasad, 2003). Infection rates of up to $33 \%$ of eggs laid by an infected hen have been documented (Shiraprasad, 1997; Wigley et al, 2001).

\section{CONCLUSIONS}

Although S. gallinarum isolation was not attempted, detection of antibodyto this organism suggests infection.A further study to include bacterial isolation in the entire poultry stock in the state

\section{REFERENCES}

Abdu, P. A. (2007). Manual of Important Poultry Diseases in Nigeria $\left(2^{\text {nd }} e d\right)$. MacChin Multimedia Designers, Zaria, 42-47.

Abubakar, M.B., El-Yuguda, A.D., Yerima, A.A. and Baba, S.S. (2008). Seoprevalence of active and passive immunity against egg drop syndrome 1976 (EDS 76) in village poultry in Nigeria.Asian Journal of Poultry Science, 2: 58-61.

Adamu, A.Y., Ahmed, A.B., Abubakar, M. B. and Lawal, M. D. (2009). A retrospective study $(2004-2008)$ of poultry diseases diagnosed in veterinary teaching hospital (Vth), Usman Danfodiyo University Sokoto (UDUS) and Sokoto Veterinary Centre (SVC), Sokoto State, Nigeria. International Journal of Animal and Veterinary Advances, 1(1):15-17.

Adegeye, A. L., Ikpe, A. E., Akinyodoye, V.O., Dittoh, J. S., Oluyemi, J. A. and Amakiri, S. F. (1988). Second national poultry survey. A study commissioned by the Federal Livestock Department, Federal Ministry of Agriculture, Water isrecommended. This will provide information on the status of fowl typhoid in village chickens in Nasarawa State. Such information will be useful for the development of control strategies against fowl typhoidin the state.

\section{AKNOWLEDGEMENT}

We are grateful to the government of Nasarawa State, Nigeria for providing financial assistance for this project. Every person who contributed in one way or the other towards the success of this reaseach in duly acknowledged.

Resource and Development, Ikoyi, Lagos.

Adesiyun, A.A., Bishu, G. and Adegboye, D.S. (1984). Serological survey of pullorum antibody in chickens around Zaria, Nigeria.Bulletin of Animal Health in Africa, 32: 81-85.

Adu, F. D., Edo, U. and Sokale, B. (1986). Newcastle disease: the imunological status of Nigerian local chickens. Tropical Veterenarian, 4: 149-152.

Agbaje, M., Davies, R., Oyekunle, M. A., Ojo, O. E., Fasina, F. O. and Akinduti, P. A. (2010). Observation on the occurrence and transmission pattern of Salmonella gallinarum in commercial poultry farms in Ogun State, South Western Nigeria.African Journal of Microbiology Research 4 (9): 796800.

Ahmed, A. K. M., Islam, M. T., Haider, M. G and Hossain, M. M. (2008). Seroprevalence and pathology of naturally infected salmonellosis in poultry with isolation and identification of causal agents.Journal of Bangladesh 
Agriculture University 6(2): 327334.

Ajala, M. K., Nwagu, B. I. and Otchere, E. O. (2007). Socio-economic of free -range poultry production among agropastoral women in Giwa Local Government Area of Kaduna State, Nigeria. Nigerian Veterinary Journal, 28 (3): 11-18.

Akter, M. R., Choundury, K. A., Rahman, M. M. and Islam, M. S. (2007). Seroprevalence of salmonellosis in layer chickens with isolation, identification and antibiogram study of their causal agents.Bangladesh Journal Veterenarian Medicine, 5(1\&2): 3942.

Animal Health and Veterinary Laboratories Services (2012). Fowl typhoid (Salmonella gallinarum): Information for Farmers and Veterinarians in Great Britain.

Arbelot, B., Dayon, J. F., Mamis, D., Gueye, J. C., Tall, F. and Sumb, F. (1997). Sero survey of dominant avian diseases in Senegal: Mycoplasmosis, Fowl typhoid and Pullorum disease, Newcastle, Infectious bursal and Infectious bronchitis diseases. Revue d' Elevage et de Medicine Veterinarier des Pays Tropicaux. 50: 197-203.

Arsenault, J., Letellier, A., Quessy, S., Normand, $V$. and Boulianne (2007). Prevalence and risk factors for Salmonella spp and Campylobacter spp. caecal colonization in broiler chicken and turkey flocks slaughtered in Quebec, Canada. Preventive Veterinary Medicine, 81:95-101.

Barrow, P. A. (1993). Salmonella Control-Past, present, and future. Avian Pathology, 22: 651 - 669.

Barrow, P. A., Berchieri, A.Jnr and AlHaddad, O. (1992). Serological response of chickens to Salmonella gallinarum - Salmonella pullorum detected by enzyme-lincked immunosorbent assay. Avian Diseases, 36:227-236.

Bell, J. G., Kane, M. and Lejan, C. (1990). An investigation of disease status of village poultry in Mauritania.Preventive Veterinary Medicine, 8: 291-294.

Bouzoubaa, K., Lemainguer, K. and Bell, J. G. (1992). Village chickens as reservoir of Salmonella pullorum and Salmonella gallinarum in Morocco.Preventive Veterinary Medicine, 12: 95-100.

Calnek, B. W (Ed) (1995). The Mack Veterinary Manual.( $\left(8^{\text {th }}\right.$ ed). MacChin Multimedia Designer, Zaria, 42-47.

Chrysostonne, C. A. A. M., Bell, J. G., Denney, F. and Verhulst, A. (1995). Seroprevalence to three diseases in village chickens in Benin.Preventive Veterinary Medicine, 22: 257-261.

Emikpe, B.O., Oluwayelu, D. O., Ohore, O. G., Oladele, O. A. and Oladokun, A. T. (2005). Serological evidence of chicken anaemia virus in Nigerian indigenous chickens.Ondersteeport Journal of Veterinary Research, 72: 101-103.

Fasure, A. K., Deji-Agboola, A. M. and Akinyemi, K. O.(2012). Antimicrobial resistance patterns and emerging fluoroquinolone resistance Salmonella isolates from poultry and asymptomatic poultry workers. African Journal of Microbiology Resesrch 6(11): 26102615.

Falade, S. and Ehizokhale, M. (1981). Salmonella and Escherichia coli strains isolated from poultry in Ibadan, Nigeria. Bulletin of Animal Health and Production in Africa, 29:99. 
Federal Department of Livestock and Pest Control Services (2010). Annual animal health report on the notification of the absence or presence of all diseases in Nigeria. FDLPCS, Abuja, Nigeria.

Federal Department of Livestock and Pest Control Services (2011). Projected poultry population in Nigeria.FDLPCS, Abuja, Nigeria.

Field Manual of Wildlife Disases (2001). Salmonellosis. Information and Technology Report, 1999-2001. Section 2, chapter 9, page 1-10.

Habib-ur-Rahman, Sirzani, S., Hamayun K., Saleem K., Nazir A. and Bhatti, W. M. (2003). Incidence and gross pathology of salmonellosis in chicken in Hyderad.Journal of Association of Veterinary Advances, 2:581-584.

Haider, M. G., Hossain, M. G., Hossain, M. S., Chowdbury, E. H., Das, P. M., and Hossain, M. M. (2004). Isolation and characterization of Enterobacteria associated with health and disease in Somali chickens. Bangladesh Journal of Veterinary Medicine, 2: 15-21.

Hassan, D. I., Yusuf, N. D., Musa-Azara, I. S., Ari, M. M., Ogah, D. M., Alaga, A. A and Elayo, S. A. (2013). Prevalence of Newcastle disease in village chickens reared in Lafia, Nasarawa State, Nigeria. Egypt. Poult. Sci. Vol (33) (1): 135142

Ibu, J. O. (2008). Studies on Newcastle disease virus isolates from Nigerian feral birds and their potentials as vaccine strains. A Ph.D thesisin the Department of veterinary Pathology and microbiology, University of Nigeria, Nsukka.

Islam, M. M., Hossain, M. M., Haider, M. G., Chowdhury, E. H. and Kamruzzaman,

M.(2006)

Seroprevalence and pathological study of Salmonella infections inlayer chicken and isolation of causal agents.In: Proceedings of the $5^{\text {th }}$ International Poultry Show and Seminary from 01-03 March 2007, Held in Bangladesh China Friendship Conference Centre (BCFCC), Sher-e-Bangla, Dhaka, Bangladesh $9-15$.

ISO 6579. (1993). Microbiology general guildline on methods for the detection of

Salmonella.Internationnal

Organization of Standardization, Geneva, Switzerland.

Jordan, F. T. W. and Pattison, M. (1996). Poultry diseases, London: W. B. Saunders Company Ltd.

Kim, C. J., Nagaraja, K. V. and Pomeroy, B. S. (1991). Enzymelinked immunosorbent assay for the detection of Salmonellaenteritidis infection in chickens.American Journal of

Lee, Y. J., Mo, I. P and Kang, M. S. (2005). Safety and efficacy of Salmonella gallinarum 9R vaccine in young laying chickens.Avian Pathology, 34(4): 362-366.

Mbuko, I. J., Raji, M. A., Ameh, J., Saidu, L., Musa, W. I. and Abdul, P. A. (2009) Prevalence and seasonality of fowl typhoid disease in Zaria-Kaduna State, Nigeria.Journal of Bacteriology Research 1(1): 001-005.

Mdegela, H. R., Yongolo, G. S.; Minga, U. M. and Olsen, J. E. (2000). Molecular epidemiology of Salmonella gallinarum in chickens in Tanzania.Avian Pathology 19:457-463.

Mona, I. E., Zakia, A. M. A., Sadek, M. A. and Darwish, H. M. (2012). Preparation and evaluation of ELISA polyvalent antigen for detection of Salmonella infection among poultry. World Applied Sciences Journal, 20(6), 806-811. 
Mozaffor, K.M., Hossain, M.T., Yamato, I (2010). Seroprevalence of Salmonella and Mycoplasma gallisepticum infection in chickens in Rajshahi and surrounding district of Bangladesh.International Journal of Biology, 2 (2): 74-80

National Agricultural Extension and Research Liaison Services (NAERLS, 2000). Improving the performance of local chickens. Extension Bulletin No. 92, Poultry Series Ahmadu Bello University Zaria, Nigeria.

Nwobu, G. O., Adekeye, J. O., Addo, P.D and Ezeokoli, C.D. (1990). Prevalence of fowl typhoid, bacteriological and serological identification in Plateau State, Nigeria.Nigeria Journal of Biotechnology, 2(4): 45-49.

Office International Des Epizooties (OIE) Manual of Standards for Diagnostic Tests and Vaccines (2000). Fowl typhoid and pullorumdisease.http://www oie.int/. Chapter 3.6.5, pp. 1-12.

Office International Des Epizooties (OIE) Terrestrial Manual of Standards for Diagnostic Tests and Vaccines (2008). Fowl typhoid and Pullorum disease. http://www oie.int/.Chapter 2.3.11, pp. 538-548.

Office International Des Epizooties (OIE). Manual of Standards for Diagnostic Tests and Vaccines and Standards (2005). Fowl typhoid: Institute for International Cooperation in Animal Biologics. http:/www. clsph. iastate. edu. Chapter 3.1.16.pp. 1-3

Ohore, O.G., Ozegbe, P. C., Emikpe, B. O. and Oluwayelu, D. O. (2002). The Prevalence of antibodies to fowl typhoid in indigenous Nigerian chicken (Gallus gallus domestic). Bulletin of Animal Health and Production in Africa, 50 (1): $63-65$.
Okwori A.E.J., Hashimu, G. A., Adetunji, J. A., Okeke, I. O. and Junaid, S. A. (2007). Serological survey of Salmonella gallinarum antibody in chickens around Jos, Plateau State, Nigeria. Online Journal of Health and Allied Sciences, 6 (2): 1-6.

Oluyemi, J. A. and Roberts, F. A. (1979). Poultry Production in Nigeria.National Animal Production Research Institute Publication, 163186.

Onunkwo, O. and Onoviran, O. (1978). Serological survey of mycoplasmosis and pullorum diseases in Plateau State of Nigeria.Kenyan Veterinarian, 2: 33.

Peter, W., Nathan, M. L and Jesca, L. N. (2006). Seroprevalence and excretion status of Salmonella pullorum-gallinarum in chicken around Kampala Uganda.African Journal of Animal and Biomedical Sciences, 1 (1): 45-46

Quinn, P. J., Carter, M. E., Markey, B. K., Donnoly, W. J. and Leonard, F. C. (2002). Veterinary microbiology and microbial diseases 1666-1117 Osney Mead, Oxford first LTd, Registered at the United Kingdom.

Rahman, M. R., Shahinuzzaman, A. B. M., Saha, A. K., Sufian, M. A., Rahman, M. H andHossain M. M. (2011). Prevalence of Salmonella infection in naturally infected layer birds in Bangladesh. The Bangladesh Veterinarian 28 (1): 818.

Roa, G. (2000). A Comprehensive Textbook on Poultry Pathology.Medical publisher Ltd.pp. 7-10

Salami, J. O., Egbulem, B. N., Kwaga, J. K. P., Yusufu, H. T., Abdu, P. A. (1989). Diseasediagnosed in poultry in Kaduna, Nigeria (1981- 
1985). Bulletin Animal Health Production in Africa. 37: 109-114.

Saidu, L., Abdu, P. A., Umoh, J. U. and Abudallah, U. S. (1994).Diseases of indigenous chickens.Bulletin ofAnimal Health and Production in Africa, 42:19-23.

Selvan, A., Gunaseelan, L., Senthil Kumar, K. and Sekar, M. (2010). Assesement of carrier status of Salmonella pullorum and Salmonella gallinarum infection in healthy flocks. Tamilnadu Journal of Veterinary and Animal Sciences 6 (2): $99-101$.

Shivaprasad, H. L. (2003). Pullorum disease and fowl typhoid. In: Saif, Y. M., Barnes, H. J., Glisson, J. R., Fadly, A. M. McDoughald, L. R., Swayne, D. E. (eds) Diseases of Poultry, $10^{\text {th }}$ edu. lowa Sate University Press. Ames, I A pp 568579.

Shivaprasod, H. L. (1997) Pullorun disease and fowl typhoid. In: Calnek, B. W., Barnes, H. J., Beard, C. W. McDougald, L. R.; Saif. Y. M. (eds), Disease of Poultry, $10^{\text {th }}$ edn., lowa State University Press, Ames, 1A. pp $82-96$.
Silva, E. N., Snoeyenbos, G. H., Weinack, O. M. and Smyyser, C. F. (1981). Studies on the use of 9R strain of Salmonella gallinarum as a vaccine in chickens. Avian Disease 25(1): $38-52$.

Valiente Moro, C., De Luna, C. J., Tod, A., Guy, J. H., Spangano, O. A. E. and Zenner, L. (2009). The poultry red mite (Dermanyssius gallinae): a potential vector of pathogenic agents. Experimental and Applied Acarology 48: 93-104.

Wigley, P., Berchieri, A., Page, K. L., Smith, A. L and Barrow, P. A. (2001). Salmonella enteric serovar pullorum persists in splenic macrophages and in the reproductive tract during persistent disease free carriage in chickens. Infection and Immunity, 60:78737879.

Wigley, P., Hulme, S., Powers, C., Beal, R., Smith, A. and Barrow, P. (2005). Oral infection with the Salmonella enteric serovar Gallinarum 9R attenuated live vaccine as a model to characterize immunity to fowl typhoid in the chicken. BMC Veterinary Research, $1(2): 1-10$ 